\section{GEOLOGISTS IN CANADA.}

I $\mathrm{N}$ recording in our columns the proceedings of the British Association at Toronto last August, passing reference was made to the excursion to the Pacific coast which was to take place at the close of the meeting. This excursion was in every way such an unqualified success, and especially from the point of view of the geologist, that we think some further account will be ac. ceptable to British geologists who were unable to attend the meeting.

It was indeed a tour which could not but make a lasting impression upon all of us who took part in it. The vast extent and diversity of the country traversed ; the richness of the material resources of the Dominion of Canada; the energy and enterprise of its inhabitants; the orderly conditions of the new civilisation even in the remotest settlements, were features which could only be properly appreciated after an experience of this kind. And beyond these general impressions it was scarcely possible for the student of any branch of science to traverse the great continent without accumulating fresh material and fresh ideas in his own particular subject. Amid a panorama of scenery always interesting and sometimes magnificent, we were carried from ocean to ocean in the greatest comfort, in many parts of the course through stretches of mountain and forest which but for the railway would have been absolutely impenetrable for the traveller however well equipped.

The arrangements for the excursion were made by the Local Committee in Toronto, who invited a limited number of the visiting members of the British Association to take part in it. To these members the Canadian Pacific Railway Company munificently presented tickets for the whole length of their main line, with the privilege also to travel without cost over any of their branch lines. A special car was attached to each of the west-bound trains leaving Toronto on three consecutive days, and remained at the service of the members until they reached the Pacific coast. The excursion party thus resolved itself into three groups, which were so arranged by the Local Committee that those of like interests should as far as possible travel together.

The geologists and their friends the geographers formed the third of these groups, leaving Toronto in the sleeping car "Chaudière" on the noon of Friday, August 27. They were especially fortunate in having for their leaders Dr. G. M. Dawson, the Director of the Canadian Survey, and Prof. A. P. Coleman, of the Toronto University and the Bureau of Mines of Ontario, men whose knowledge of the country to be traversed was so intimate that no point of interest could escape unnoticed. Among the members of our party were Dr. W. T. Blanford, Prof. W. C. Roberts.Austen, Dr. C. Le Neve Foster, Prof. Albrecht Penck (of Vienna), Prof. W. M. Davis (of Harvard), Prof. K. Huerthle (of Breslau), Sir George Robertson, Prince Kropotkin, Prof. H. E. Armstrong, Colonel F. Bailey, Prof. T. Hudson Beare, Dr. H. O. Forbes, Mr. W. E. Hoyle, Dr. A. Harden, Dr. J. Scott Keltie, Mr. G. W. Lamplugh, Dr. H. R. Mill, and Prof. H. A. Miers.

From the very outset the geological interest of the journey was continuous. Scarcely had we left Toronto when Prof. Coleman pointed out to us the long stretches of the Iroquois beach, an ancient tilted shore-line of Lake Ontario. Next we passed for three or four hours over an irregular plain of drift, beneath which lay hidden the almost undisturbed Palæozoic rocks of this region. After skirting the shores of Lake Simcoe, we crossed the great unconformity, and found ourselves upon that vast Archrean protaxis which was thenceforward to te traversed for a distance of over I100 miles almost without interruption. Night closed on the characteristic scenery of this Archran country - a timbered wilderness with hummocky rocks, everywhere smoothed and polished by glaciation, rising into low hills and enclosing lakes and lakelets innumerable with swamps or sluggish drainage channels between. Lake Nipissing, with its ancient terraces, through which it is believed that the outflow of the Upper Great Lakes once found its way into the Ottawa River, was passed in the night. In the morning we found ourselves "side-tracked" at Sudbury, in the centre of a mining region, which already produces fully one-half of the world's consumption of nickel, and could supply more.

With that energetic hospitality which met us at every halt, the Mayor of Sudbury, with a local committee of reception, was early astir with a carefully arranged plan for the day. After a public breakfast a special engine was at hand to take the "Chaudière" and its occupants to the renowned Copper Cliff Mines.
Through the admirable forethought of Dr. Dawson, who struck something akin to awe into us by his power of conjuring up in the most unlikely places whoever or whatever we might most desire, Mr. A. E. Barlow, of the Canadian Survey, had made his appearance on the train during the night from his camp in the woods, and was ready to give us the benefit of his intimate knowledge of the district. With him and Prof. Coleman as our guides, we studied to the best advantage. at the outcrop, the mode of occurrence of these great deposits of nickeliferous pyrrhotite and chalcopyrite which apparently are segregated in an area of gabbro near its contact with granite. We were then shown through the surface works of the mine, the managers pointing out to us each stage in the reduction of the ore, from its initial crushing and roasting to its smelting into " matte," in which form it is sent east for further refinement. Some of these processes were especially interesting to the metallurgists and chemists of our party.

On leaving this mine we divided into two companies, those who were anxious to see more of the nickel-mines visiting Denison, about twenty miles west of Sudbury, where the prospectors were developing an ore-deposit similar in character to that of Sudbury, but remarkable as containing also some platinum in the form of the rare arsenide, sperrylite, and a little gold. Here some of the earth overlying the ore-deposit was panned out, and a fair show of grains of sperrylite obtained.

The other members were conveyed by their special engine to Fairbank, a few miles distant, whence they went in wagons over a terribly rough "corduroy" road to a place in the woods where a curious vein of carbonaceous material had been struck, which its discoverers hoped might prove a valuable source of fuel. This material, known as anthraxolite, though not a true coal in the ordinary sense, is composed of almost pure carbon. It occurs in this place as an irregular upright vein, in some parts several feet in width, somewhat interpenetrated by quartz. This vein cuts across the bedding of the surrounding dark carbonaceous slaty rocks, which are either of Lower Cambrian or of Huronian age.

At this place, as we wound our way along the forest trail towards the luncheon place, there was a sudden and for the moment inexplicable stampede of the foremost members of the file, who had unwittingly plunged into a hornet's nest, and suffered inconvenience in consequence. And this little accident was the only mishap of the whole journey !

After luncheon a further expedition was made in birch-bark canoes up the Vermilion River, for three or four miles, to a spot on Vermilion Lake where a shaft had been sunk to develop another vein of the anthraxolite, but where its mode of occurrence was not so clearly seen. On regaining our vehicles, we were conscious on starting of a sense of loss, and then perceived that our two most prominent foreign members were missing. We discovered them, however, placidly eating pie in the logcabin of a settler. They eagerly explained that they were "studying the customs of the country"-a phrase which thenceforward acquired a special significance.

In returning to Sudbury our train was stopped to allow $\mathrm{Mr}$. Barlow to point out an intrusive contact of the Laurentian granite upon the brecciated edge of the diorite (Huronian?), which appears to be the normal relation of the two rocks in this region. This makes it somewhat difficult to understand how the metalliferous ore has been concentrated at the original margin of the basic mass.

In the evening we were banqueted by the citizens, and after many mutually complimentary speeches retired to the "Chaudiere" with the consciousness of a well-spent day,

The morning of the 29th found us traversing a sparsely inhabited region of lakes and forests to the north-east of Lake Superior. The rocks were for the greater part of Laurentian type, a matted complex of igneous intrusions mostly of granitic character, but presenting now and again a more basic "Huronian" aspect. The marks of glaciation were everywhere visible, on a scale quite inconceivable to the British glacialist-in fact, one might say that this whole day's journey w'as across a huge glaciated surface.

And here it may be remarked, as illustrating the immense scale of the glacial phenomena of North America, that throughout the whole of our journey of 3000 miles we were never at any one point outside the limits of the glacial deposits, and that in one shape or another the evidences of former glaciation were always visible from our car windows. Moreover, we might have gone eastward from Montreal for an additional 750 miles, 
to the shores of the open Atlantic, with still the same glacial surroundings !

In the early afternoon at Heron Bay, Lake Superior lay below us, and until nightfall our course ran through the bold and picturesque scenery of its cliffy margin. Old beach-terraces lying high above the present lake were pointed out to us in many places, these being the margins of different stages of the ancient glacier-dammed lake of vast extent to which the names Warren, Nipissing, \&c., have been applied.

Towards evening there came a change in the profile of the land, striking alike to the geologists and the geographers, the familiar low hummocky outlines of the Archæan giving place to the bolder features of broad tabular rock-masses rising high above the lake with cliff-like sides, the bright red tints of which were strongly accentuated by the setting sun. These masses are composed of Lower Cambrian rocks (Animikie and Keweenawan), chiefly red sandstones and shales with some thin limestones, preserved under a capping of columnar diabase, which rest with the most pronounced unconformability, cakelike, upon the irregular Archæan floor, like the Torridon Sandstone on the gneiss in the North-west Highlands.

As if the elements themselves were imbued with the spirit of Canadian hospitality, not only was the weather almost throughout our tour everything one could desire, but also on this particular evening there came a fine display of aurora borealis to charm us when darkness had hidden the land.

The following day, August 30 , we arrived early at Rat Portage, the chief mining centre of Western Ontario, where we found Mr. McInnes, of the Canadian Survey, just in from his camp to meet us. Here again we were received by the principal citizens, and led at once to the wharf on the beautiful Lake of the Woods, where a special steamboat had been chartered for us. The extremely interesting Archæan geology of this region has been made known to European geologists by the classic Canadian Survey Memoir of Prof. A. C. Lawson, and we rejoiced in the opportunity to examine some of the sections described by him. Our first object was to visit the highly suc. cessful Sultana gold mine on an eastern arm of the lake. On the way thither we stopped to land at one of the Indian Reservations, where a curious native burial-ground had attracted our attention; and the pathetic mementos which decorated a child's grave exciteci our somewhat too obtrusive interest. Later in the day we were enabled to visit a second camp, and see something of its living inhabitants.

At the Sultana Mine, where a mill of ten stamps is already at work and a number of additional stamps are being erected, we were shown the process of treating the ore, which is largely free-milling, only 20 per cent. of the gold being left in the concentrates for recovery by the chlorination process. The metal occurs in a quartz vein, at one place admirably exposed at the surface, which traverses the country-rock near the contact of granite, said to be Laurentian, with Huronian diabase. Throughout the Dominion it appears to be in similar positions around the contact of intrusive masses that the chief metal. liferous deposits are found.

Led by Prof. Coleman, to whom this whole region is familiar, and by Mr. McInnes, we next ascended the hill to the east of the mine, and further examined the junction of the so-called Laurentian granite with the Huronian rocks, and noted the intrusive character of the former. Then rejoining our steamer we went westward to some islands in the lake, on which the agglomeratic and apparently volcanic character of the Huronian rocks was well displayed.

The waters of the lake were thick with a minute green floating organism, probably an alga. It is said that there are 13,000 islands in this lake alone; which may be an over-estimate, but they are certainly very numerous. We were told that they were to be bought at all prices, from five dollars upwards, so that the possession of a private island in this part of the world need not be an expensive luxury. And it might, perchance, hold a goldmine !

Spending the night at Rat Portage the geologists were early astir next morning, and found time for further investigation of this interesting locality. Under Prof Coleman's guidance we studied the contact of Laurentian and Huronian at several points to the westward of the town, near where the waters of the lake pour through three distinct outlets to form the Winnipeg River. It can scarcely be said that our investigations enabled us to grasp the complex relationship of these great rock-groups, though in some of the sections the gneissic Laurentian seemed clearly to be irtrusive upon the Huronian. But the general impression to be gathered from all we saw of these rocks was that the term Huronian might include very different rocks in different places, and that still more was this the case with the term Laurentian. Until the Post-Archæan rocks are reached no strict divisional lines seem possible. Upon such difficult problems as these of the oldest rocks, however, the casual observer of a few isolated sections has really no right to own an opinion.

The enormous water-power which the Lake of the Woods contains, has to a slight extent already been utilised at one or the other outlet, in the production of an electric supply for the city, and for driving extensive flour-mills at Keewatin. But a fine dam is now nearly finished by which the whole outflow will be made available for industrial purposes, and it has even been proposed to convey the power to Winnipeg over 100 miles distant. The navigation of the lake between Rat Portage and Keewatin had lately been much impeded by a floating island of vegetation, but this, as we saw, had been surrounded with a boom of logs, and fixed to the shore.

Boarding the train again at Keewatin, our course lay for a few hours longer through typical Archæan country ; but gradually the old rocks sank beneath the drift-plain, and before reaching Winnipeg in the afternoon we had passed once more on to a hidden platform of the Older Palæozoics, and had reached the edge of the great prairies. We were now within the basin of the glacial Lake Agassiz. This extinct lake is believed by its explorer, Mr. Warren Upham, to have extended eastward well beyond the Lake of the Woods, and westward to the "second prairie steppe" of Dr. Dawson, a breadth of about 250 miles, while the length from its termination southward in Minnesota to its northern shore against the ice-sheet north of the present Lake Winnipeg may have been nearly 700 miles; its area has been given as about I IO,000 square miles, or greater than the total of the six existing great lakes, Superior, Michigan, Huron, Erie, Ontario and Winnipeg! It is to its finer sediments that the wonderfully productive character of the soil of the Manitoba prairies is largely due.

At Winnipeg, the "half-way house" of the continent, the west-bound trains stop for an hour and a half to refit. With special tram-cars at our service, we were thus able to see something of this substantial city with its many handsome buildings. The old Hudson Bay post, Fort Garry, standing in their midst, reminded us how marvellously rapid has been the growth of this western capital.

On the evening of August $3 \mathrm{I}$, with Winnipeg behind us, the crossing of the plains had fairly commenced. Some writer-it must surely be Lawrence Sterne--has pointed out the great value of a plain to the discursive recorder of trayels. One could not do better than follow this preceptor by setting down here some general reflections which might otherwise find no place for themselves.

First, we have to regret how few in number were the British geologists to avail themselves of this magnificent opportunity for study. It is often urged against us, and not without reason, that we are too insular in our ideas and too apt to ignore the work done beyond our borders. Certainly the geologist who confines his attention solely to the neat details of British stratigraphy can scarcely hope to realise the true proportions of the problems with which the earth-student must deal. Explanations of phenomena which seem quite applicable on the small scale, often reveal their essential inadequacy under wider conditions of application. And for a corrective study of broad conditions this transcontinental journey must assuredly be unrivalled.

The railway goes more or less at right angles to the strike of the continent, and traverses therefore all the main rock. masses of which the land is built, and all the great structural features by which it is diversified. Hence the final impression which the geologist receives is that of some vast diagrammatic section of a continent. Even the scant time spent in making the traverse was, on this occasion, compensated for by the presence of the men who knew all that is yet known of the route, and who were always ready to impart what they knew.

Next, although in the abstract patriotism is out of place in science, let us record the sense of gratification felt by the British members of the party, that across the breadth of this wide and prosperous Dominion we were among brothers. One could scarcely make a journey of this kind without becoming a little more Imperialist than before.

Then let us set down our admiration for the work of the

NO. 1464, vOL. 57] 
Canadian Geological Survey. Considering the means at its command, and the positively inconvenient extent of its territory, it is marrellous how nuch has already been accomplished, and how clearly the general structure of the country has been brought out. It was pleasant to ubserve, ton, how well its work was appreciated among the people for whom it was primarily intended, and how in the mining districts the geological maps we carried were quite familiar to the prospectors and mining people generally, who were usually themselves furnished with copies.

And now for the Plains: They were a knotty problem for our geo morphologists, not easily to be solved by "base-level. ling" or other faniliar methods, and we crossed them without properly understanding then. Considering their elevation, it is clear that they should not remain so flat!

But, taking them as we found them, we passed during the night from the first or Red River Plain to the second steppe, where there are some undulations, and before noon had the long ridge-like Missouri Côteau, which is largely made ip of glacial detritus, and is probably morainal in origin. We then reached the third steppe, which has an elevation of a little over 2000 feet above sea-level at its eastern edge,

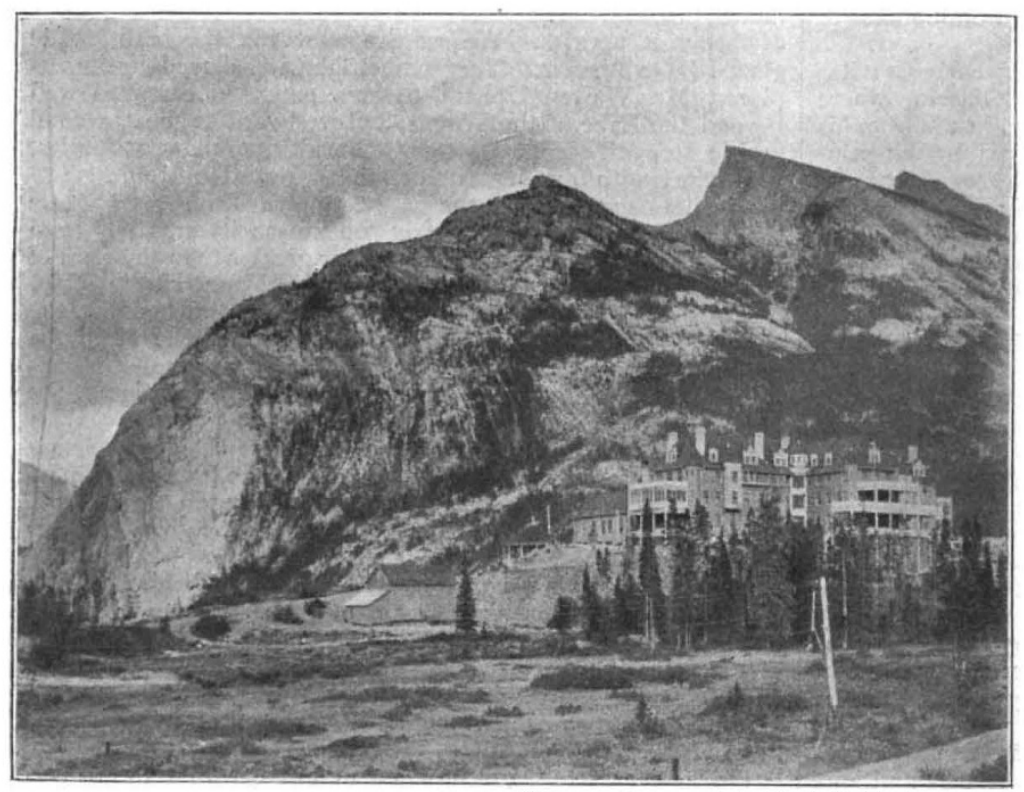

[From a photograph by Prof. H. E. Armstrong.

FIG, 1.-The western or dip-slope of Mount Rundle ( 9635 feet) ; a faulted and tilted mountainblock, chiefly of Devono-Carboniferous Limestones. From Banff Hot Springs. into the mountains. crossed this also, and had reached that remarkable feature

As we approached the mountains we saw how the Laramie and Cretaceous rocks graclually lost their horizontality, beconing more and more tilted and crumpled as the foot-hills were traversed, until-at the entrance to the mountains-the disturbances suddenly culminated in a magnificent overthrust, as clearly visible on the bare mountain-wall as in a text-book diagram. By this thrust the Cambrian, Devonian, and Devono-Carboniferous limestones have been driven eastward over the broken Cretaceous strata for a horizontal distance estimated by $\mathrm{Mr} \mathrm{R}$. G. McConnell at seven miles, with a vertical displacement of $1_{5}, 000$ feet.

We stopped just long enough at Kananaskis to gain a clear impression of this grand section, and were then taken forward

From this point onward the line afforded a constant succession of studies for the geologist which could not fail to arouse his enthusiasm. The boldly-bedded character of the strata, with the planes often picked out by new snow, the steepness of the slopes, and the absence of vegetation, combined to bring out with the utmost distinctness details of structure which ordinarily can be discovered only after infinite labour and research. Infold and overfold, syncline and anticline, thrust-plane and fault were alike visible. Under such conditions the study of mountain-structure acquired a fresh significance, and even those of us who before had paid no attention to the subject now pursued it with zest.

The general character of this region is summed up as follows in the admirable report of Mr. McConnell ${ }^{3}:$ " "This portion of the Rocky Mountains .... is characterised in its eastern part by a series of great fractures and thrust faults, in the centre by broad sweeping folds, and in the west by folding and crumpling, accompanied by the development of cleavage. planes and a limited amount of metamorphism. Among its other more important features may also be noted the absence of recognisable unconformities, the absence of any of the older crystalline schists, the relatively smaller amount of disturbance in the central parts of the range than towards the edges, the want of similarity in the sequence of the formations east and west of the axis, and the marked preponderance of calcareous beds between the Middle Cambrian and the Cretaceous."

Our course lay up the Bow Valley, which is here carved out of a trough of Cretaceous rocks, wedged in among and apparently overlain by Cambrian strata. In this trough coal is mined, and although on the Plains the coal of Cretaceous age is lignite of poor character, the quality improves as the mountains are approached, until in this district both bitu. minous coal and anthracite are obtained.

but rises gradually to over $40 c 0$ feet at the foot of the Rocky Mountains. These plains are all underlain by Laramie and Cretaceous rocks lying flat and undisturbed, containing seams of lignite, and in places yielding natural gas. There were few sections, however, either natural or artificial, excepting in the superficial drift deposits. In these drifts boulders of Lauren. tian rock are very numerous, many hundreds of miles from their source. The third steppe is almost entirely a cattle-ranching country. with a dry cliniate, as is indicated by the numerous salt lakes visible from the railway. In crossing it, the Cypress Hills, an outlier of Miocene rocks, broke the horizon to the southward, and the surface generally became more diversified than in the lower steppes.

At Medicine Hat, in the evening, we crossed the South Saskatchewan, and under ordinary circumstances should have ent. rod the Rocky Mcuntains during the nisht. But our director determined that we must make the approach Iy daslight, and gave orders that nur car should be detached in the night at Calgary, where at daybreak the long range of motntain peaks was just in view. A special engine had been conjured from somewhere, and stood ready to take us forward to Banff. By this arrangement, what was for the geologist the most impressive part of the route was seen to full advantage.

NO. I 464 , VOL. 57$]$
Not only in geological interest but also in the beauty of its mountain scenery the Canadian Pacific is undoubtedly far superior to any other line crossing the North American continent. We were here within the limits of Canada's Rocky Mountain National Park, and the views we now obtained delighted us. Arriving at the well known tourist centre, Banff, about noon, and establishing ourselves at the large new C.P.R. Hotel, where we found Prof. John Macoun of the Canadian Survey awaiting us, we set about to make the best of our time. A ridge, known as Sulphur Mountain, rising 3000 or 4000 feet above the valley to the west of the hotel, proved at tractive to the more energetic of our party, and although Prof. Macoun had already made the ascent earlier in the day, he expressed his readiness to start again, and undertook the leadershp of the cromp. For the olluers, wha were content to view the many points of interest in the beautiful valley, carriastes were provided.

Frum the grand outlook on the crest of Sulphur Mountain the chief leatures of the region were readily grasped. The Buw River far below us broke across the range, while on either hand were deep longitudinal valleys running between tilted oru. graphic blocks of Palazozoic limestones, out of which a succes1 Canadian Survey Reports for 1886 , vol, ii. Report D, p. 40. 
sion of mantainous ridges had been carved. all with precipitous faces to the east, and long dip-slopes to the west. Near the summit, a oout 8000 feet above sea-level, there were distinct traces of glaciation, apparently transverse to the ridge.

A hurried descent put us into fit state to appreciate the luxury of a bath from one of the hot sulphur springs, already cclebraterl for their restorative properties, which well up along a line of fault at the foot of the mountains. Then after a reunion at the hotel we retired once more to the "Chaudière," which had begun to assume quite a home-like aspect.

Early on the following morning, September 3, the west-bound train took us again in tow, our course for some time following up the Bow River amid scenery of increasing splendour, with glaciers showing here and there in the mountains ahead. Then, turning westward up a small tributary, the train entered the Kicking Horse Pass ; and soon a painted signboard announced the Continental Divide; and we breakfasted at Field Station on the Pacific slope, with the shapely Mount Stephen just above us. From this point onward the geological structure became more complex, the foldings more acute, and the outline of the mountain peaks less and less dependent upon the bedding, and in running down the beautiful valley of the Wapta or Kicking Horse to the Upper Columbia depression we passed into the region of complication and alteration which forms the core of the mountain ranges. Thenceforward to the Pacific coast the task of the travelling geologist is difficult, and but for the work which has already been published on the Selkirks and Coast Ranges, and the presence among us of the man who had done it, we should have been at a loss to understand what we saw.

The Columbia River was reached at Golden, and was followed thence northwestward to Beaver Mouth. The great terraces of stratified material which line its valley up to high levels attracted attention both here and at Revelstoke, where the railway again crosses the river below its great north bend. Leaving the Columbia, our track turned south-westward, up Beaver Creek and Bear Creek, to make its difficult traverse of Selkirk Range. The Palæozoic rocks had now undergone a great change of character, and instead of the flaggy limestones of the Eastern Rockies, we found ourselves among unfossiliferous argillite schists and quartzites, everywhere highly disturbed and sheared. The denser timber and the many long snow-sheds lent additional obscurity to our genlogical impressions.

Around Rogers' Pass, 4300 feet above sea-level, lies the finest mountain scenery of the whole route, but on this day the highest tops were hidden in clouds. A short run from the summit brought us, at 2 p.m. or I 4 o'clock railway time, to our next halting-place, the C.P.R. Hotel at Glacier.

At this place our first objective was, of course, the grand Illicilliwaet Glacier, the snout of which lies two miles back in the forest. Around the glacier a busy afternoon was spent-one of sur party, expert in such work, fixing points for measuring its future recession; others scaling the lateral moraines of blocks of sheared quartzite in which blue quartz grains were conspicuous; others attacking the glacier itself, and studying the fine display of structures which the body of the ice reveals. But the time was, of course, too short for more than a mere skirmish around its lowermost portion, and the great icefields above remained unseen.

It had been proposed on the following morning to climb one of the ridges overlooking these icefields; but here for the first and only time the weather failed us, and though after breakfast I'rof. Coleman, who made light of all obstacles, led the way towards the Asulkan, another of the many glaciers of this region, he found but few followers to face the discomfort of the saturated forest.

Some curious feats in engineering have been performed in carrying the railway down the western slope of the Selkirks, but none are more remarkable than the great "loops" by which the descent is made from Glacier into the cañon of the Illicilliwaet. After leaving this place we had all around us the heavy timber of the Pacific region, making, where unburnt, a fine foreground to the peaks and glaciers behind. But the wholesale devastation which has been wrought by forest fires throughout this region is distressing to any eyes but those of the Western man who has come to regard timber as the chief hindrance to the rapid development of his country.

At Albert Cañon the train stopped long enough to allow our photographers to spoil their plates in attempting views of a sombre river-gorge. At this point the dark schists with a band of crystalline limestone (part of the "Nisconlith Series" of Dawson) are believed to lie very near the base of the sedimentary rocks of the Selkirks. At any rate, a short distance further west we entered upon the region of gneiss, mica-schist and granite, which the Canadian geologists recognise as a portion of the Archran nucleus or axis. Out of such rocks the western part of the Selkirks and much of the Gold Range have been carved. We found opportunities to examine them, during the return journey, at a few points around Revelstoke and Arrowhead, and from their intricate structures one might judge that several different stages of movement and several distinct periods of eruption were represented. Unlike the conditions in Eastern

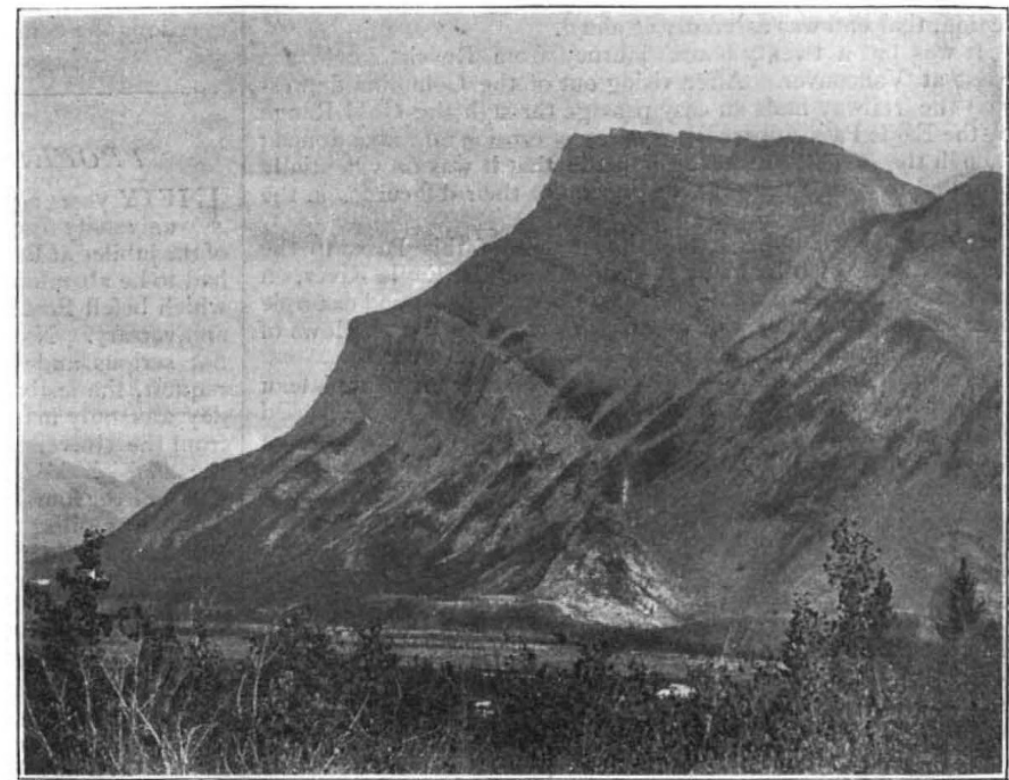

[From a photograph ly Prof. H. F. Arinstrong. FIG. 2,-The eastern face of Mount Rundle, Banff.

Canada, in British Columbia westward of the Selkirks the Palæozoic and even Mesozoic rocks are so involved and altered among eruptive and intrusive masses, and so implicated with each other by the earth-forces which have built up the mountainranges, that the evidence for age is rarely at hand, and one would need to be thoroughly well acquainted with the country to pronounce upon any part of it. But one could see that these schists and gneisses form the Central Complex of the ranges; and they seem of high antiquity. In travelling from east to west across the mountains we had seen the effects of crustal forces of gradually increasing intensity, acting ustally from west to east. We were now upon the focus of these forces, where their intensity had obscured the evidence.

At Revelstoke, the same evening, the Columbia was crossed for the second time, the great river flowing south-easterly here, instead of north-westerly as where we had crossed it on the previous day, on nearly the same latitude, but about 150 miles nearer its source. The valley systems of this part of the cuntinent are peculiarly interesting for the physiographer, and present some curious problems which are yet unsulved. In this instance the Columbia and its great tributary, the Knotenay, have their sources close together in the same great valley: the one flows north, and then swings round sharply southward; the other

NO, $146+101.57]$ 
flows south, and swings northward to their union, the Selkirks and associated mountain ranges being thus completely encircled. Among our party were those who have struggled bravely with such problems, and to their investigations we shall look for further enlightenment.

From Revelstoke the C.P.R. Company has a line of communication by rail and steamboat into the celebrated West Kootenay mining district, by way of that beautiful expansion of the Columbia River known as the Arrow Lakes. Through the liberality of the British Columbian Government, side-excur. sions were organised into this region, and on our return from Vancouver the majority of our party took advantage of the opportunity to visit the brand-new mining town of Rossland, around which are grouped the chief mines of the district. Here, as everywhere else in the province, every facility was afforded us to see all that was best worth seeing. We visited such wellknown mines as the Le Roi, War Eagle, Centre Star, \&c., where large deposits of auriferous chalcapyrite and pyrrhotite occur, chiefly in veins near the margin of a mass of gabbro intrusive into Palæozoic rocks. The large smelter at Trail, on the Columbia Railway, a few miles distant, was also visited; and those of us who could spare the time went afterwards into the Slocan country, where the richest mines of silver-lead occur. Space forbids a detailed account of these and other branch excursions in the Province; but if it was intended that we should come away impressed with the mineral wealth of the region, that end was assuredly attained.

It was but a twenty hours' journey from Revelstoke to the coast at Vancouver. After rising out of the Columbia depression the railway finds an easy passage through the Gold Range by the Eagle Pass, apparently a valley of erosion now abandoned ; though the suggestion had been made that it was providentially supplied to compensate the engineers for their difficulties in the Selkirks and the Rockies.

A chain of small lakes fills the summit of this Pass, to the westward of which lie many fine moraines. In Eagle River, on its western slope, we were fortunate in witnessing a good example of a salmon run, shoals of great fish crowding the shallows of the stream in every part, and lying dead on every bar.

Shuswap and Kamloops Lakes, and the dry interior plateau of British Columbia with its Tertiary volcanic rocks, were passed in the night, and at daybreak of September 5 we were running down the picturesque cañon of the Thompson River, near its junction with the Fraser. In the Fraser Valley itself there is in this neighbourhood a sharp infold of Cretaceous strata; but lower down we saw only ancient-looking slates, supposed to be Cambrian, along with masses of igneous rocks, both of acid and basic types. Near North Bend, where we breakfasted, a dredger was at work raising the auriferous gravel from the river bed. Below this the valley narrows, and the Fraser races southward for miles through a magnificent cañon, down which the railway also passes. Then, at Yale, the river bursts out of the mountains and swings round westward into a broader and apparently much older valley, which it follows from Hope to the Pacific. Following the river, our track went now amid the dense forest of gigantic trees with which the valley is filled, cleared spaces being as yet quite scanty. Of the Laramie or newer rocks which underlie the Fraser delta, we saw nothing, as on the low ground there is everywhere drift and alluvium. Reaching Pacific tide-water at the head of Burrard's Inlet about noon, we drew up at Vancouver half an hour later.

Our long delightful railway journey was completed, and with it our transverse section of the continent. Starting within the Appalachian rim, we had seen, to the east of the prairies, the old Archæan floor on which the Palæozoic strata rested almost undisturbed; then the prairies themselves, with their vast expanses of horizontal, unfaulted Mesozoic rocks; then the foothills, with the same rocks thrown into wavelike swells; then the outer mountains, with dislocated and overthrust masses of various ages, driven eastward from the centre of disturbance then the inner ranges, with crumpled and altered strata whose age was no longer determinable, and with the central core of metamorphic and plutonic rocks; and then again, to the westward, infolded and crumpled sediments with many igneous interruptions.

All this had, of course, been described for us already by the Canadian geologists in their admirable official and other publications. But what literature could hope to convey an adequate impression of such a region to one unacquainted with it ?

At Vancouver most of us took boat at once across the Straits of Georgia, a few on whom time pressed crossing to Nanaimo, and the majority going first to Victoria, whence a special excursion was afterwards made to Nanaimo. It was a glorious afternoon for the passage - the mountains around Howe's Sound half hidden under storm-clouds and half revealed, and a foreground of high gloomy shores, with the deep recesses of the fjords within gleaming with mysterious light.

On Vancouver Island the heartiest hospitality again awaited us, but of our doings there is small space left to tell. In Victoria we found many of our friends of the two earlier parties, and we of the "Chaudière" held a banquet to do honour to our leaders Dr. Dawson and Prof. Coleman. On Monday we were taken in carriages to the points of chiet interest in the vicinity of the city; on Tuesday there was a special train to take us to Nanaimo, where coal of excellent quality is extensively mined from rocks of Cretaceous age ; and on Wednesday a number of those who intended to visit the Kootenay started for the mainland. Safe to say that we all left the city of Victoria with reluctance, as most do who visit it.

And now the unity of our party was lost, and its fortunes need be no further followed. For all of us this had been a memorable journey, and we started homeward with a lively sense of gratitude to the Local Committee at Toronto, to the Provincial Governments of Ontario and British Columbia, to the Canadian Pacific Railway Company, and, above all, to our leaders Dr. G. M. Dawson and Prof. A. P. Coleman, by whose exertions the complete success of the excursion was secured.

\section{PROFESSOR VIRCHOW'S JUBILEE.}

FIFTY years ago Prof. Virchow delivered his first lecture as a $\mathrm{F}$ university teacher, and preparations for celebrating the event of the jubilee at Berlin last week had been made, but unfortunately had to be abandoned in consequence of a sudden attack of illness which befell Prof. Virchow whilst lecturing two days before the anniversary. Naturally some alarm was felt, but the attack was not serious and passed off quickly. However, at Virchow's request, the festive arrangements were countermanded, and the day was only marked officially by a congratulatory deputation from the University. According to the Berlin correspondent of the British Medical Journal the deputation consisted of the deans of the four Faculties, and nearly all the medical professors. Prof. Schmoller, the University Rector, spoke first, and in a warm and able address praised Virchow as the benefactor of millions, and as the great instructor whose methods had gradually permeated almost all schools of thought. Then followed Prof. Heubner, the Dean of the Medical Faculty. $\mathrm{He}$ spoke of Virchow's strong personality, and described the com. manding impression caused by his teachings which had revolutionised medical thought. It was true that what might be called Virchow's greatest lifework was the introduction of " methodology" into medicine, but this alone did not explain his immense influence. He had pre-eminently the genius of research, and had traded with his talent as a faithful steward. At an age when others had not finished their studies he had attacked scientific problems with his bold and strong intellect, had gone on from problem to problem, until after ten years his work was crowned by the completion and publication of his "Cellular Pathology." Since then he had become the praceptor mundi in medicine. Prof. Virchow, in reply, modestly disclaimed what he called excessive honours. He said he felt like a plant from which the withered leaves had been removed to give it a better appearance. He could not deny that his work had always been full of zeal, and supported by the endeavours to keep in view universal principles ; and it was true, also, that a certain soberness of judgment had helped him over great difficulties. If he had succeeded earlier than others in forming a school, he owed this to his recognition of the fact that it was impossible to do everything oneself, and to his success in creating a sort of phalanx for his ideas, which had been of sufficient force to overcome resistance, and to prepare a broad basis for later developments. And thus, he was happy to say, he now felt himself no longer indispensable as representing his school, since there were a sufficient number of men sharing his views. $\mathrm{He}$ hoped that his little attack of the day before would have no further consequences, and that he had yet some time for work before him ; still he could not hide from himself that it was now time to make a stop, to a certain extent; and therefore he was

$$
\text { NO. I } 464 \text {, VOL. } 57 \text { ] }
$$

